\title{
Using the Carolingian Past in a Society of Transformation: The Case of Early Medieval Septimania/Catalonia in the Long Tenth Century (900-1050)
}

\section{Matthias M. Tischler*}

The north-eastern region of the Iberian Peninsula, which later became medieval Catalonia, and the adjacent French region, then called Septimania, formed an intermediary zone of ethnic, cultural, linguistic, social, political, and religious transition and brokerage between the Mediterranean and central European worlds, interfacing with the Christian north and Muslim south. Consequently, the double region Septimania/Catalonia is an ideal subject for a comparative view of transformation processes in the Carolingian Empire. My paper - giving an interim report on ongoing research - analyses how this still-underestimated periphery of the Carolingian Empire transformed into a central region of Latin Christian Europe between the late ninth and the middle of the eleventh century, through exploring its imported and autochthonous manuscript production and its position as a border society. In doing so, I show that the societal and religious circumstances of this intermediary zone favoured the concerted selection, introduction and implementation of the core results of the Carolingian Church reform, as well as its well-balanced adaptation to a post-Roman, post-Visigothic and post-Carolingian society under reconstruction. My reflections allow us to assess the quality of "Carolingian« culture as an imperial, i.e. overarching, eclectic and flexible concept of amalgamation of cultural and political semantics, from a peripheral rather than a central European perspective.

Keywords: Carolingian Church reform; texts and transmission; manuscript studies; centres and peripheries; Carolingian Empire; Septimania; Catalonia; border societies

* Correspondence details: Prof. Dr. Matthias M. Tischler, Institució Catalana de Recerca i Estudis Avançats/Universitat Autònoma de Barcelona, Edifici B, Campus de la UAB, E-08193 Bellaterra, Spain; email: Matthias.Tischler@ uab.cat. 
The central focus of my paper is not to show how »Carolingian « early medieval Septimania/ Catalonia was in the long tenth century (900-1050), ${ }^{1}$ nor to present the huge bulk of Carolingian manuscript transmission of this period and beyond, ${ }^{2}$ nor to demonstrate that this region north and south of the Pyrenees formed a historical, ecclesiastical and cultural unit. ${ }^{3}$ Nor do I reiterate an overly narrow focus on selected manuscript material from the famous Benedictine abbey of Ripoll and some other Catalan places of manuscript culture from the ninth to the late tenth century alone, motivated by a political conception of "Carolingian" which is erroneous and deserves complete revision. ${ }^{4}$

My central aim is to present an overarching and precise view on the Carolingian manuscript culture of this region we still know today and to identify the power and effects of identitybuilding represented in the specific features of this manuscript legacy. In other words, my focus is on the intriguing question of what Carolingian text corpora were used and not used, and how they were used for the transformation of a deeply Romanised Mediterranean society which - having been a periphery of the former Visigothic kingdom - showed cultural, legal and theological traces of this Hispanic world. The other point of my paper results from precisely this cultural and political constellation: after the end of the Visigothic dominion in the Iberian Peninsula following the Arabo-Berber conquests in 711, the opportunity to establish new Christian dominions in southern Gaul and the northern and north-eastern regions of the peninsula formed new intellectuals in this Hispano-Gaulish middle ground. These men then developed text models which became central for the further text culture we now call »Carolingian.$^{5}$

3 Mundó i Marcet, El pes, 48-49, who already showed the continuity of cultural and monastic contacts between Catalonia and Septimania even after the late tenth century. In the following, my focus lies especially on the Catalan manuscript evidence, but - if already identified among the even less-investigated Septimanian manuscript legacy - I also mention copies from religious institutions north of the Pyrenees. I explicitly stress the provisional character of my results due to the unsatisfying state of the art of manuscript research in Septimania/Catalonia.

4 The massive Carolingian text transmission of the ninth to twelfth centuries in Septimania and Catalonia (as $\mathrm{n}$. 1-2) speaks against the picture of early medieval Catalonia built on a highly selective manuscript basis offered by Chandler, Carolingian Catalunya, 189-228.

5 In the following all mentioned manuscripts are quoted without their related bibliography, which can be checked under pagines.uab.cat/unup/content/materials. 
Key figures such as Benedict of Aniane, ${ }^{6}$ Smaragdus of Saint-Mihiel ${ }^{7}$ and others ${ }^{8}$ promoted the introduction of revised and new forms of monastic and religious life and their normative text corpora. ${ }^{9}$ Therefore, we should not be astonished by the early wide-spread presence of the so-called Narbonne recension of the Rule of St. Benedict in ninth- to eleventh-century Septimania/Catalonia, ${ }^{10}$ nor by the availability of a corpus of exegetical work on its content and meaning. ${ }^{11}$ Both these corpora guaranteed a unified form of monastic life in this region.

6 Kettemann, Subsidia Anianensia.

7 Rädle, Studien.

8 To name only Theodulf of Orléans: Dahlhaus-Berg, Nova antiquitas; Freeman and Meyvaert, Theodulf of Orléans; Agobard of Lyon: Boshof, Erzbischof Agobard von Lyon; Claudius of Turin: Boulhol, Claude de Turin.

9 Excellent overviews on the introduction of Benedictine life in early medieval Catalonia are: Linage Conde, Los orígenes, 498-538; Linage Conde, L'implantació.

10 On the Iberian manuscript transmission and diffusion of the Rule: Linage Conde, Los orígenes, 777-788 and 844-854. The text family of the rare Iberian testimonies depends on an archetype stemming from Narbonne or Septimania, the home region of Benedict of Aniane: Hanslik, Praefatio, liv-lv and lviii; Díaz y Díaz, La circulation des manuscrits, 238 n. 132; Zimmermann, Écrire et lire 2, 762. Ríu i Ríu, Revisión, 96 indirectly assumed that it was Benedict of Aniane himself who brought this version of the Rule to the Spanish March during his mission to Urgell. The earliest Septimanian testimony was a now-lost manuscript of the late eighth century still existing at the end of the seventeenth century in the library of a canon of Narbonne Cathedral and collated by D. Estiennot for Jean Mabillon and Edmond Martène. The collation is preserved in Paris, Bibliothèque nationale de France, MS lat. 12772, pp. 137-143. The earliest known Iberian copy of this text family from c. 850 is still written in Visigothic minuscule, but seemingly under the influence of Carolingian minuscule and thus produced in a religious centre of a north-western Catalan county (Sant Vicenç de Gerri?), today El Escorial, Real Biblioteca del Monasterio de San Lorenzo, MS I. III. 13., fols. 7v-57v. Further preserved copies from the eleventh century are Paris, Bibliothèque nationale de France, MS lat. 4209, fols. 1r-2or, unidentified Catalan Benedictine house, Barcelona, Arxiu de la Corona d’Aragó, MS Sant Cugat 22, fols. 135v-155r, Sant Cugat del Vallès (given to its foundation Sant Llorenç del Munt), and København, Det Kongelige Bibliotek, Ny Kgl. Samling, MS 1794, fols. 185r-201v, Santa Maria de Serrateix, before 1076. Other early copies are attested in the book inventory of Sant Sadurní de Tavèrnoles from 1040 (one, if not two exemplars) and in the Ripoll catalogue of 1047, perhaps the (now-lost) personal exemplar of Abbot Oliba. Gellone later also participated in the history of the recensio Narbonensis with Montpellier, Bibliothèque municipale, MS 13, fols. 37r-83v, thirteenth century.

11 This explicatory work has three branches: a) exegetical tracts on the Rule in the proper sense; b) propagandistic texts in favour of the Rule; and c) the hagiographical production on Benedict of Aniane. For a) the central work is Smaragdus of Saint-Mihiel's Expositio in Regulam S. Benedicti. Beyond an early Septimanian copy of the third quarter of the ninth century, Paris, Bibliothèque nationale de France, MS lat. 4213, fols. 1v-18ov, we have a single folium from a tenth-century copy from Sant Benet de Bages, Montserrat, Arxiu i Biblioteca del Monestir, MS 793/I, and the "Espositum regule» in the Ripoll catalogue from 1047 was most probably also a copy of this commentary. A further copy is mentioned in the catalogue of the Septimanian Benedictine abbey of Saint-Pons-de-Thomières of 1276. Barcelona, Arxiu Capitular, Còdex 120, fragment no. 2, Septimania, ninth century, shows glosses on the Rule ch. 5-7, the spiritual core of the work. This fragment belonged to a glossary on the Regula S. Benedicti which explained the Rule chapter by chapter in commenting central words or passages of the text. For b) one has to mention Benedict's Concordia regularum, a synopsis of regulations taken from different monastic rules, transmitted in an abbreviated text version (with lacunae) in a Septimanian copy of the late ninth century, today Tarragona, Biblioteca pública, MS 69, fols. 1r-176r. Two further traces of Benedict's works are Montserrat, Arxiu i Biblioteca del Monestir, MS 847, fols. 59r-62v, a fourteenth-century copy perhaps from Saint-Victor de Marseille of his tract De diversarum poenitentiarum modo de regula Benedicti distincto, a special short comparative text on various monastic penitence practices, and Montserrat, Arxiu i Biblioteca del Monestir, MS 995, fols. 136r-137v, Girona, Sant Pere de Gallicants, fifteenth century, with Benedictus Levita's Collectio capitularium III additio I, a revised version of Benedict of Aniane's Capitulare monasticum. The only Catalan copy of Smaragdus of SaintMihiel's famous monastic speculum, the Diadema monachorum, is the twelfth-century copy from the Benedictine abbey Sant Cugat del Vallès, Barcelona, Arxiu de la Corona d'Aragó, MS Sant Cugat 9o, fols. 1v-124v. For c) we have traces of Benedict's Life written shortly after his death (821) by his own pupil Ardo of Aniane (c. 822/823) in the lectionary of Serrateix, Solsona, Arxiu Diocesà, Còdex 33 (olim Museu Diocesà, MS 3), fols. 23v-24r, and in the (lost) two-volume breviary of Saint-Michel de Cuxa, here first volume, fols. 63-64, attested by the table of contents in Paris, Bibliothèque nationale de France, Fonds Baluze, MS 372, fols. 44r-48v, here fol. 44v. 
Though it is very often forgotten, the same holds true for the canonical life, since we now know of a handful of early tenth- and eleventh-century copies of the Aachen rule for canons from $816^{12}$ which remained influential in some of the »unregulated « - that is, non-Augustinian - Septimanian and Catalan cathedrals and canonical communities, until the late Middle Ages. ${ }^{13}$

We should not forget that the implementation of these Empire-wide unified religious normative orders and lifestyles north and south of the Pyrenees did not merely demonstrate the presence of Carolingian rule in this south-western Mediterranean zone; instead, it was more a theological necessity, since it was the best means to establish the practice of orthodox Catholic faith in the old and new monasteries, cathedrals and clerical communities of a deeply Romanised society affected by the "Hispanic « heresy of Adoptionism. ${ }^{14}$

The well-known struggle of Carolingian theologians against the main protagonist of this erroneous Christological position, Bishop Felix of Urgell, ${ }^{15}$ set off an avalanche of religious, exegetical, theological and juridical texts of Carolingian provenance which transformed the ecclesiastical and cultural landscape, especially of Catalonia, during the ninth, tenth and eleventh centuries. We know that beside Alcuin and Paulinus of Aquileja - whose relevant works of Catholic faith instruction were also available in Catalan copies ${ }^{16}$ - Benedict of Aniane and Leidrad of Lyon were central figures in this battle for Christian orthodoxy south of

12 The oldest known copy in our region is Paris, Bibliothèque nationale de France, MS lat. 1534, fols. 1r-115r, Aachen court scriptorium for Carcasonne Cathedral, first quarter of the ninth century. The copy mentioned in the Vic inventories of Bishop Guadamir from 957 and Bishop Atto from 971 is perhaps the existing manuscript Vic, Arxiu i Biblioteca Episcopal, MS 128 C (XLVII C), fols. 1v-45v, written in an unidentified Catalan scriptorium of the middle of the tenth century. Further testimonies are the lost exemplar Sant Joan de les Abadesses, Arxiu del Monestir, s. n., Sant Joan de les Abadesses (?), eleventh century, Vic, Arxiu i Biblioteca Episcopal, MS 44 (XXXVI), fol. 84va-144vb, Vic Cathedral, 1064/1065, and the lost copy of La Seu d'Urgell, mentioned in the inventories from c. 1100 and 1147 respectively, perhaps the exemplar produced on occasion of the reform of the community of canons of Urgell Cathedral under Bishop Ermengol in 1010. An enigmatic, perhaps Septimanian tenth-century copy is Paris, Bibliothèque nationale de France, MS lat. 17649, fols. 1r-38v, which was in Paris, Notre-Dame, in the seventeenth century.

13 This is shown by Vic, Arxiu i Biblioteca Episcopal, MS 130 (III), fols. 101va-116rb, Vic, fourteenth century (before 1340), and Girona, Biblioteca Diocesana del Seminari, Fons de Manuscrits de Sant Feliu de Girona, MS 17 (olim Seminario, MS 150; olim Archivo de San Félix, MS 16), fols. 104ra-16ora, Girona, Sant Feliu, 1502.

14 On the preaching activities of Benedict of Aniane against Adoptionism in the diocese of Urgell: Ríu i Ríu, Revisión, 91-92; Bonnery, À propos, 785. Benedict's Visigothic background, but pro-Frankish theological position were important arguments against the wrong "outfashioned« theology of Felix's Adoptionism: Cavadini, Last Christology, 82, 115, 128-130, 184 n. 7, 185 n. 10, and 191 n. 64; Chandler, Heresy and empire, 525-526.

15 Cavadini, Last Christology, 1, 4, 8, 71-102, 107-127, 156 n. 90, 159-160 n. 113, 163-164 n. 135 and 137, 184 n. 5, 191 n. 62-63., 192 n. 69 and 74, 196-197 n. 102, and 198 n. 108-109; Perarnau i Espelt, Feliu d'Urgell; Perarnau i Espelt, Jornades internacionals.

16 Alcuin, De fide sanctae et individuae Trinitatis and De Trinitate ad Fredegisum quaestiones XXVIII: Cavadini, Sources. The manuscripts are Paris, Bibliothèque nationale de France, MS lat. 2341, fols. 158ra-166rb and 166rb167ra, Orléans region, second quarter of the ninth century (843), later Ripoll, tenth or eleventh century, later Le Puy Cathedral; Vic, Arxiu i Biblioteca Episcopal, MS 43 (LXXX), fols. 62ra-95rb and 95rb-98va, Vic, 1056/1057, written by the Vic canon and scribe Ermemir Quintilià; Vic, Arxiu i Biblioteca Episcopal, MS 47 (LXXXVIII), fols. $80 v-115 \mathrm{r}$ and $115 \mathrm{r}-117 \mathrm{r}$, Italy, twelfth century. Paulinus of Aquileja, Liber exhortationis ad Hericum comitem: Vic, Arxiu i Biblioteca Episcopal, MS 43 (LXXX), fols. 30ra-57va, Vic, 1056/1057, written by the Vic canon and scribe Ermemir Quintilià; Tarragona, Biblioteca pública, MS 105, fols. 1r-70r, Santes Creus, twelfth to thirteenth century, with various additions. 
the Pyrenees. ${ }^{17}$ What has not yet been realised and described, is that the panorama of the wider religious, pastoral, liturgical and theological Carolingian text culture introduced in early medieval Septimania/Catalonia was mainly formed by authors who were members of the school of Lyon or whose works were intellectually related to this learned circle of Visigothic and Frankish clerics.

The most prominent case in this field of text transmission is certainly the dissemination of the Martyrology by Ado, former monk of Ferrières and Prüm, who, before becoming archbishop of Vienne (860-875), redacted this text in Lyon between 850 and 859 on the basis of Bede the Venerable, Florus of Lyon and the so-called Martyrologium Romanum Parvum, a version he had made himself. ${ }^{18}$ Up to the twelfth century, his work was the exclusive collection of short biographical notes and texts on the saints venerated in many early medieval Septimanian and Catalan institutions of Benedictine, ${ }^{19}$ canonical or clerical denomination, ${ }^{20}$

17 On Benedict: as n. 6. On Leidrad: Cavadini, Last Christology, 82, 185 n. 10, and 189 n. 50 . A central gateway of Carolingian religious and theological influence was the Abbey of Sant Sadurní de Tavèrnoles (near La Seu d'Urgell), which, before the Benedictine reform by Benedict of Aniane (799/800), had been a hotspot of Felix of Urgell's Adoptionism: Baraut i Obiols, Monestir, 254-255 and 259; Delcor, Monastère, 43-46, 48-49 and 61.

18 The martyology is transmitted in two families and the first family again has three recensions, probably all by Ado, whereas the second family is the result of redactional work by someone else: Quentin, Martyrologes historiques, 465-675; Dubois and Renaud, Martyrologe d'Adon, xx-xxvii. The following overview of manuscripts is an update of Iglesias i Fonseca, »Martirologio«.

19 København, Det Kongelige Bibliotek, Ny Kgl. Samling, MS 1794, fols. 3r-173r, Santa Maria de Serrateix, before 1076; Barcelona, Arxiu de la Corona d'Aragó, MS Sant Cugat 22, fols. 1v-135r, Sant Cugat del Vallès, eleventh century. In addition, the book inventory integrated in the charter of the church dedication of Sant Sadurní de Tavèrnoles from January 17, 1040 mentions two martyrologies, and the Ripoll catalogue of 1047 even three martyrologies. A later Septimanian copy is Montpellier, Bibliothèque municipale, MS 13, fols. 1r-36v, Saint-Sauveur de Gellone, thirteenth century.

20 Girona, Arxiu Capitular, MS 3, fols. 1ra-131vb, Girona, middle of the tenth century or c. 960/980 (copy of the priest Richarius); Vic, Arxiu i Biblioteca Episcopal, MS 128 A (XLVII A), fols. 1r-140v, Vic, end of the tenth century (980-100o); Paris, Bibliothèque nationale de France, MS lat. 5256, fols. 14r-146r, Carcassonne, 1046/1055; Vic, Arxiu i Biblioteca Episcopal, MS 128 B (XLVII B), fols. 1ra-143vb, Vic, 1061; (†) Sant Joan de les Abadesses, Arxiu del Monestir, Carpeta 539, no. 3, Sant Joan de les Abadesses, eleventh century; Sant Joan de les Abadesses, Arxiu del Monestir, s. n., fol. 1r-3v, Sant Joan de les Abadesses (?), eleventh century; Vic, Arxiu i Biblioteca Episcopal, Fragm. XII/13, fols. 1r-2v, Vic (?), twelfth century; Vic, Arxiu i Biblioteca Episcopal, MS 129 (XLIII), fols. 1ra$106 \mathrm{vb}$, Vic, before 1196. This martyrology continued to be used as can be seen in the cases of Vic, Arxiu i Biblioteca Episcopal, MS 130 (III), fols. 1r-82v, Vic, fourteenth century (before 1340), Paris, Bibliothèque nationale de France, MS lat. 5255, fols. 10ra-37vb, Narbonne, Saint-Étienne, fourteenth century, and Girona, Biblioteca Diocesana del Seminari, Fons de Manuscrits de Sant Feliu de Girona, MS 17 (olim Seminario, MS 150; olim Archivo de San Félix, MS 16), fols. 7r-103r, Sant Feliu de Girona, 1502. Further copies of martyrologies, probably also by Ado of Vienne, are mentioned from the early tenth century onwards, as in the testament of Bishop Riculf of Elne (915) and in the inventory of Bishop Guadamir of Vic (June 14, 957), which could have been the same manuscript that is also mentioned in the inventory made after the death of Bishop Atto of Vic (August-September 971). In some cases, the medieval provenance is still unknown: Vilanova del Vallès, Arxiu parroquial, fragment s. n., Catalonia, twelfth century, and two late-twelfth-century copies which showed typical local feasts and important necrological entries pertaining to Catalonia and were preserved until 1811 in the library of Montserrat Abbey. 
since only from then onwards did the new French communities of the Augustinians from Saint-Ruf d'Avignon and the Cistercians in Catalonia substitute this edition with the Carolingian Martyrology of the ninth-century Benedictine monk Usuard of Saint-Germain-des-Prés. ${ }^{21}$

Another prominent case demonstrating the significant influence of the Carolingian school of Lyon in our zone is the wide use of the Liber officialis, the main work of Amalar, who, since summer 835, had administered the Archbishopric of Lyon for several years and had taught and disseminated there his comprehensive allegoric interpretation of the Christian liturgy. ${ }^{22}$ Copied and read in Septimanian and Catalan Benedictine and Cistercian houses ${ }^{23}$ and also by canonical and clerical communities ${ }^{24}$ at least up to the thirteenth century, Amalar's work, alongside Walahfrid Strabo's rarely transmitted Libellus de exordiis et incrementis quarundam in observationibus ecclesiasticis rerum, ${ }^{25}$ became central for the introduction of the common Roman liturgy.

21 Tortosa, Arxiu Capitular, MS 90, fols. 34r-94r, Southern France, middle of the twelfth century; New York, Hispanic Society of America, B 2715, fols. 12r-82r, Sant Miquel d'Escornalbou, end of the twelfth century; Vic, Arxiu i Biblioteca Episcopal, MS 207, fols. 1r-23v, Catalonia (Vallbona de les Monges?), twelfth to thirteenth century; Tarragona, Biblioteca pública, MS 106, fols. 206r-287v, Santa Maria de Bonrepòs, twelfth to thirteenth century. A late medieval deluxe copy is Girona, Museu Diocesà, MS 273, fols. 7r-96v, Bohemia, early fifteenth century.

22 Steck, Liturgiker Amalarius, 9-11, 15 n. 63, 103, 105-118, 195 and 199.

23 Already mentioned in the Ripoll catalogue of 1047, two existing copies from the eleventh century show that the text was then available and used in Catalonia. The first copy from early eleventh-century Ripoll, Tarragona, Biblioteca pública, MS 85, fols. 1r-120v, written by the famous scribe Guifred, is certainly one of the manuscripts mentioned in the Ripoll catalogue. The other copy, Barcelona, Biblioteca de Catalunya, MS 944, fols. 5v-121r, is also from Ripoll, but from later in the same century, and already shows awareness of the Gregorian Church reform because of texts belonging to this period of transition. A third copy from the twelfth to thirteenth century, Tarragona, Biblioteca pública, MS 66, fols. 105r-113v, from Santes Creus, presents only excerpts, but shows the unbroken popularity of this Carolingian work in Catalonia. Barcelona, Arxiu de la Corona d'Aragó, MS Ripoll 206, fols. $134 \mathrm{v}-156 \mathrm{r}$ from the same period transmits Pseudo-Amalar of Metz, Eclogae de ordine Romano et de quattuor orationibus episcoporum sive populi in misa. The two copies that remained in Ripoll are still mentioned by Benet Ribas in his catalogue under the nos. 76 and 162; it is probable that these Ripoll manuscripts are Barcelona, Biblioteca de Catalunya, MS 944 and Barcelona, Arxiu de la Corona d'Aragó, MS Ripoll 206. A further copy is mentioned in the catalogue of the Septimanian Benedictine Abbey Saint-Pons-de-Thomières from the year 1276.

24 An eleventh-century copy is attested in the testament of the judge, sexton and cantor of Vic and abbot of Àger who donated it to his cathedral after his death (October 17, 1082). The majority of this library was the former personal collection of the Vic canon, scribe and mecenas Ermemir Quintilià (who himself got many books from the Vic canon Guillem Hiquilà), who delegated it to Guillem Ramon in 1081 with the purpose of donating it to the altar of St. Michael in Vic Cathedral at the time of his death. Another possible copy of the work is mentioned in the book inventory of the basilica of Saint-Aphrodise in Béziers from the year 1162.

25 Barcelona, Arxiu de la Corona d'Aragó, MS Ripoll 206, fols. 102r-134v, Ripoll, twelfth to thirteenth century; Tarragona, Biblioteca pública, MS 66, fols. 105r-113v (excerpts), Santes Creus, twelfth to thirteenth century. 
A third text corpus which exerted a massive influence on the reform of the former Visigothic churches in our intermediary region is constituted by the copies of the new Carolingian Church Law collections, the Collectio Dacheriana and the Collectio Dionysio-Hadriana. The first was perhaps redacted by the Visigoth Agobard, the later archbishop of Lyon, who widely based his work on the Collectio Dionysio-Hadriana, commissioned by Pope Hadrian I in 774, and the systematic collection of the Visigothic Church of Toledo, the Collectio canonum Hispana. ${ }^{26}$ It was a hybrid solution which combined Roman and Hispanic canon law and whose knowledge and use is attested through ninth- and eleventh-century copies in Ripoll and Vic. ${ }^{27}$

The more prominent Carolingian collection of the Collectio Dionysio-Hadriana appears to have been introduced in the Catalan dioceses and monasteries since the ninth century via the same route of dissemination..$^{28}$ It served as a basic source for the famous Admonitio generalis which laid the foundation for Charlemagne's reform of education in monasteries and bishoprics with the aim of establishing schools for grammar and the liberal arts in order to promote learned monks and clerics. Early ninth- and tenth-century copies of this collection are still preserved or at least attested in Urgell, Vic and Ripoll. ${ }^{29}$

The Carolingian collections of canon law offered the legal framework of the pastoral work of early medieval Catalan bishops and abbots. We still have copies of Carolingian tracts, compendia and capitularies that gave their reader detailed information on the correct form of baptism, Christian education and penance. A tenth-century copy from Girona transmits Leidrad of Lyon's Liber de sacramento baptismi, together with Theodulf of Orléans's episcopal capitularies. ${ }^{30}$ This common text transmission does not appear to be fortuitous, when we remember that Theodulf's norms were published in 798, so shortly before Benedict of Aniane, Nebridius of Lagrasse and Leidrad of Lyon were Charlemagne's Spanish "missi« in the matter of the Adoptionist affair (799/800). Leidrad's tract on the sacrament of baptism, written some years later in response to the demand of Charlemagne and dedicated to the emperor, shows his episcopal activities and his concern for pastoral care. Integrated into the

26 Mordek, Kirchenrecht und Reform, 12-13 with n. 49 and 259; Kéry, Canonical Collections, 87.

27 Paris, Bibliothèque nationale de France, MS lat. 2341, fols. 204ra-231rb, Orléans region, second quarter of the ninth century (843), later Ripoll, tenth or eleventh century, later Le Puy Cathedral; New York, Hispanic Society of America, HC 380/819, fol. 2v, Santa Maria de l'Estany, eleventh century counts under ch. 69-78 of the Capitulatio I 73-75, 82-83, 77-79, 92 and 85, but the corresponding folia are missing. Barcelona, Arxiu de la Corona d'Aragó, MS Ripoll 77, fols. 5vb-39rb with excerpts of Form B, a copy made in January 1776 by the Ripoll monk and librarian Antoni d'Olmera i Desprats, attests an early eleventh-century copy of this collection in Ripoll.

28 This suggests at least the palaeographical analysis of the preserved oldest copy mentioned in n. 29 .

29 La Seu d'Urgell, Arxiu Capitular, MS 2006, Lyon, second half or end of the ninth century; Barcelona, Biblioteca de Catalunya, MS 945, southern France (?), ninth to tenth century, later in Ripoll, tenth century. The copy in Urgell and La Seu d'Urgell, Arxiu Capitular, MS 2005, Santa Maria de Ripoll, beginning of the eleventh century, with the Collectio Hispana, are the manuscripts mentioned in the catalogues of Urgell Cathedral from c. 1100 and 1147 respectively. In addition, the testament of Bishop Idalguer of Vic from February 15, 908 also mentions a copy of the Collectio Dionysio-Hadriana, which is perhaps one of the Vic copies mentioned in the inventories of 957 (three exemplars) and 971 (three plus one exemplars) respectively. Finally, the Ripoll catalogue of 1047 mentions five copies, of which one could have been the above-mentioned copy in Ripoll. A later thirteenth-century copy of this collection from Ripoll is Barcelona, Arxiu de la Corona d'Aragó, MS Ripoll 105.

30 Barcelona, Biblioteca de la Universitat, MS 228, fols. 141r-158r and 76v-89r, Girona, sometime before 990. Leidrad's tract goes here under St. Jerome's name and shows interpolations, whereas Theodulf's work is transmitted anonymously. 
dedication letter, this tract explains the meaning of baptism, shows the biblical background of this sacrament and gives an exegesis of the rites pertaining to it. On the other hand, Theodulf recommends the establishment of parish schools in his diocese and obliges his priests to teach free of charge. The regulations thus concern the Christian education of the believers, the formation of the clergy and the bishop's pastoral care, and they seemingly found an interested audience in tenth-century Catalonia. ${ }^{31}$

The same holds true for other copies of capitularies of the Carolingian bishops such as Pseudo-Theodulf (Theodulf of Orléans's Capitulum alterum), Radulf of Bourges, Isaac of Langres and Walter of Orléans which are transmitted in early eleventh-century copies from Vic, Sant Joan de les Abadesses and Ripoll..$^{32}$ In addition to this scenario of pastoral care, the tenth- or eleventh-century book holdings of Ripoll Abbey also possessed a partial copy of Halitgar of Cambrai's penance manual De vitiis et virtutibus et ordine poenitentialium. ${ }^{33}$ The latter is also transmitted in a nearly full copy from the late tenth-century episcopal see of Girona ${ }^{34}$ and in excerpts from mid-twelfth-century Roda de Isábena, ${ }^{35}$ a fact which allows us to uncover the practice of penance at some bishoprics of early and central medieval Catalonia. ${ }^{36}$

A final central aspect of how Carolingian religious text culture transformed an early medieval border zone in transition is that of the concerted and balanced implementation of the revised text of the Vulgate and its daily reading and use in the exegetical and liturgical form of Homiliaries. From the late eighth century onwards, many Carolingian authors invested their full energy in revising the Latin text of Jerome's Bible version and in compiling new collections of homilies based on patristic and contemporary Bible exegesis. Since the state of research on the widely unexplored Latin Bible tradition of early medieval Septimania and Catalonia does not allow for a succinct qualification of the text versions that circulated in this middle ground, ${ }^{37}$ I will focus on the question of the Carolingian Homiliaries in this border zone alone. Intensified manuscript research in the last decades has uncovered a rich tradition of various Carolingian Homiliary editions, imported into and accomplished within

31 A selection of Theodulf of Orléans's Capitularies is also transmitted in the eleventh-century Vic copy of a late Carolingian edition of the acts of the Church Council of Troyes from 878, New York, Hispanic Society of America, HC $380 / 819$, fols. $1 \mathrm{r}-2 \mathrm{v}$ and 5r-28r, here fols. 7v, 9r, 10v-12r, 16v-17v and 19v-20v, later Santa Maria de l'Estany.

32 Pseudo-Theodulf of Orléans, Capitulum alterum: New York, Hispanic Society of America, HC 380/819, fols. 11r-12r; Radulf of Bourges, Capitula: ibid., fols. 5r-10v, 12r-16v and 17v-22v; Isaac of Langres, Capitula: ibid., fol. 32r/v; (†) Sant Joan de les Abadesses, Arxiu del Monestir, MS 1, Sant Joan de les Abadesses (?), eleventh century, perhaps lost in the Spanish Civil War in 1939; Walter of Orléans, Capitula: Barcelona, Arxiu de la Corona d'Aragó, MS Ripoll 40, fols. 50ra-51rb, Ripoll, c. 1020.

33 Here only Book VI: Paris, Bibliothèque nationale de France, MS lat. 2341, fols. 231rb-233rb, Orléans region, second quarter of the ninth century (843), later Ripoll, tenth or eleventh century, later Le Puy Cathedral.

34 Here Books I-V: Barcelona, Biblioteca de la Universitat, MS 228, fols. 6v-46r, Girona, sometime before 990. Since Books III-V are heavily drawn from the Collectio Dacheriana (Kottje, Bußbücher, 165), this would uncover another connection of some of this manuscript's works to the Carolingian school of Lyon.

35 Book I: Lleida, Arxiu Capitular, RC. 0022 (olim MS 8), fols. 201r-217r, Roda de Isábena, middle of the twelfth century.

36 Halitgar ist not mentioned in Zimmermann, Écrire et lire.

37 Puig i Tàrrech, Bíblia llatina. 
the Church of Narbonne north and south of the Pyrenees ${ }^{38}$ Among them, the most influential was the still largely unedited Homiliary published by a certain Luculentius around 900, which found a wide dissemination in Catalonia and Septimania from the early tenth century onwards. ${ }^{39}$ This new testimony is worthy of a full edition and detailed study, since it turns out to be a precious testimony of the religious, social and political situation of the Catalan counties at the end of the ninth century. These formed a frontier society to the pagan world of the non-Christian Iberian Peninsula which needed a complete re-Christianisation. On the basis of the Homiliary of the Visigoth Smaragdus of Saint-Mihiel, Luculentius enriched his text with further patristic and Carolingian sources, especially from the school of Auxerre (Heiric), but also added many proper observations and comments in order to analyse the present religious, social and political state of his society south of the Pyrenees against the backdrop of the sources he used in a selective, but concerted manner.

To conclude, we can say that after nearly three years of manuscript research we have produced more new questions than we have found really sound answers. At least we have stressed the massive influence that the Visigothic-Carolingian school of Lyon exerted on early medieval Catalonia, a phenomenon we completely underestimated before we started our in-depth manuscript research in the Barcelona-based HERA-project in late summer 2016. This specific feature makes sense when we remember Lyon's role in the struggle against the Adoptionism of Felix of Urgell and when we take into account too that remnants of this Christological position persisted in Catalonia and Septimania during the whole ninth century (if not even later)..$^{40}$ We also showed how deliberate and targeted were the selections of the bishops and abbots from the rich Carolingian production of new religious, exegetical, liturgical and legal works and which of them they possessed in full copies or excerpts.

38 Attested are the collections by Paul the Deacon, Smaragdus of Saint-Mihiel, Hrabanus Maurus, but also knowledge of the later Carolingian compilations by Haimo and Heiric of Auxerre or the Franco-Catalan recension of the so-called Liverani-Homiliary. A modern, comprehensive monograph on the transition from Visigothic to Carolingian liturgy in Septimania and Catalonia and on the rich history of redactions of new individual Carolingian Homiliaries of the Church of Narbonne is missing. Previous research on liturgy and music in Catalonia embedded in the broader Iberian context, especially by Alexandre Olivar i Daydí, Miquel dels Sants Gros i Pujol and Maricarmen Gómez Muntané, is documented in Zapke, Hispania Vetus.

39 Tischler, Supposed and true knowledge of the Qur'ān, 28-34; Tischler, How Carolingian, based on the excellent work done by Raymond Étaix, Joseph Lemarié, Hildegund Müller and Francesc Xavier Altés i Aguiló. The main testimonies are the two earliest, nearly complete copies Madrid, Biblioteca de la Real Academia de la Historia, MS 17 and MS 21, from Sant Cugat del Vallès, middle of the tenth century. A list of 95 further fragments of homilies of this collection from the tenth to the early thirteenth century, which needs complete revision from codicological and palaeographical standpoints, is published by Altés i Aguiló, Tradició codicològica i litúrgica, 129-200.

40 Chandler, Heresy and empire, 513-514; Chandler, Carolingian Catalunya, 117-118, who, however, does not connect his observations with the specific Carolingian text transmission in Septimania and Catalonia I tentatively outlined above. Baraut i Obiols, La intervenció, 173-188 already mentioned at least the introduction of some texts of the reformed Benedictine monasticism and of the Carolingian Roman liturgy of the Church of Narbonne, yet almost without mentioning existing early medieval manuscripts of this specific religious text culture in Catalonia. On other memories of Adoptionism in ninth-century authors of the Carolingian Empire such as Jonas of Orléans (De cultu imaginum I), Paschasius Radbertus (Expositio in Psalmum XLIV) or Hincmar of Rheims (De una et non trina deitate ch. 9): Cavadini, Last Christology, 206 n. 8. 
What still remains as a major problem is the need to give an adequate qualification of Narbonne's religious and cultural role in this manuscript panorama, since it was this metropole in Septimania which expanded south of the Pyrenees after the Muslim occupation of the dioceses of the "ecclesia Tarraconensis ${ }^{41}{ }^{41}$ Was the role of Narbonne more that of an intermediating transmitter between Aquitaine, Western Francia and Burgundy on the one hand and the Italian and Iberian Peninsulas on the other hand ${ }^{42}$ And what role did the Church of Narbonne and its religious communities play in the concert of Carolingian religious culture between centres and peripheries? Was it also an innovative zone of biblical and liturgical production in addition to its known role in the monastic history of reform-Benedictinism? ${ }^{43}$ Finally, what "writing province« did the styles of Carolingian minuscules in early medieval Septimania and Catalonia belong to? ${ }^{44}$

Ongoing research in the coming years will give more insight into this mainly unexplored middle ground intermediating between the Carolingian and the Mediterranean worlds. The more we understand the agency of this middle ground, the more we have a chance to compare it with the specific features of the other border zones of the post-Carolingian Empire and to deepen our understanding of what was "Carolingian", or not, in the centres and peripheries of an always multilayered and multiple Europe.

41 A sophisticated overview of this process of expansion is given by Vones-Liebenstein, Katalonien zwischen Maurenherrschaft und Frankenreich.

42 Magnou-Nortier, La société lä̈que et l'église; Riess, Narbonne.

43 Gros i Pujol, Liturgie narbonnaise; Olivar i Daydí, Survivances wisigothiques; Gros i Pujol, De l'església hispana a l'església carolíngia, have stressed a certain stand-alone position of the Church of Narbonne within the Carolingian reform movement also known for perpetuating orthodox liturgical text traditions of the former Visigothic Church.

44 On our still very scarce knowledge of Benedict's scriptorium in Aniane: Bischoff, Älteste Handschriften, 13-14; Engelbert, Codex Regularum, 49-52; Engelbert, Karolingisches Fragment, 147-149. On the earliest written products of the ninth- to tenth-century Benedictine and clerical communities of Catalonia: Mundó i Marcet and Alturo i Perucho, Escritura de transición; Alturo i Perucho, Cultura llatina medieval; Alturo i Perucho, Manuscrits i documents llatins; Alturo i Perucho, Escritura visigótica y escritura carolina; Alturo i Perucho, Fragment de còdex 2541, IV; Alturo i Perucho, Tipus d'escriptura a la Catalunya; Mundó i Marcet and Alturo i Perucho, Problemàtica de les escriptures, 127-131 and fig. 4-7; Arnall i Juan, Escritura carolina, 98-104. The reconstruction of the earliest palaeographical landscape of Carolingian Septimania/Catalonia on the basis of the manuscript data given in Bischoff, Katalog and beyond remains a big challenge for our future research. 


\section{References}

\section{Manuscripts}

Barcelona, Arxiu Capitular, Còdex 120, fragment no. 2

Barcelona, Arxiu de la Corona d'Aragó, MS Ripoll 40

Barcelona, Arxiu de la Corona d'Arago, MS Ripoll 77

Barcelona, Arxiu de la Corona d'Arago, MS Ripoll 105

Barcelona, Arxiu de la Corona d'Aragó, MS Ripoll 206

Barcelona, Arxiu de la Corona d'Aragó, MS Sant Cugat 22

Barcelona, Arxiu de la Corona d’Aragó, MS Sant Cugat 90

Barcelona, Biblioteca de Catalunya, MS 944

Barcelona, Biblioteca de Catalunya, MS 945

Barcelona, Biblioteca de la Universitat, MS 228

El Escorial, Real Biblioteca del Monasterio de San Lorenzo, MS I. III. 13.

Girona, Arxiu Capitular, MS 3

Girona, Biblioteca Diocesana del Seminari, Fons de Manuscrits de Sant Feliu de Girona, MS

17 (olim Seminario, MS 150; olim Archivo de San Félix, MS 16)

Girona, Museu Diocesà, MS 273

København, Det Kongelige Bibliotek, Ny Kgl. Samling, MS 1794

Lleida, Arxiu Capitular, RC. 0022 (olim MS 8)

Madrid, Biblioteca de la Real Academia de la Historia, MS 17

Madrid, Biblioteca de la Real Academia de la Historia, MS 21

Montpellier, Bibliothèque municipale, MS 13

Montserrat, Arxiu i Biblioteca del Monestir, MS 793/I

Montserrat, Arxiu i Biblioteca del Monestir, MS 847

Montserrat, Arxiu i Biblioteca del Monestir, MS 995

Montserrat, Arxiu i Biblioteca del Monestir, s. n.

Montserrat, Arxiu i Biblioteca del Monestir, s. n.

New York, Hispanic Society of America, B 2715

New York, Hispanic Society of America, HC 380/819

Paris, Bibliothèque nationale de France, MS lat. 1534

Paris, Bibliothèque nationale de France, MS lat. 2341

Paris, Bibliothèque nationale de France, MS lat. 4209

Paris, Bibliothèque nationale de France, MS lat. 4213

Paris, Bibliothèque nationale de France, MS lat. 5255

Paris, Bibliothèque nationale de France, MS lat. 5256

Paris, Bibliothèque nationale de France, MS lat. 12772

Paris, Bibliothèque nationale de France, MS lat. 17649

Paris, Bibliothèque nationale de France, Fonds Baluze, MS 372

(†) Sant Joan de les Abadesses, Arxiu del Monestir, MS 1

(†) Sant Joan de les Abadesses, Arxiu del Monestir, Carpeta 539, no. 3

(†) Sant Joan de les Abadesses, Arxiu del Monestir, s. n.

La Seu d'Urgell, Arxiu Capitular, MS 2005

La Seu d'Urgell, Arxiu Capitular, MS 2006

Solsona, Arxiu Diocesà, Còdex 33 (olim Museu Diocesà, MS 3)

Tarragona, Biblioteca pública, MS 66 
Tarragona, Biblioteca pública, MS 69

Tarragona, Biblioteca pública, MS 85

Tarragona, Biblioteca pública, MS 105

Tarragona, Biblioteca pública, MS 106

Tortosa, Arxiu Capitular, MS 90

Vic, Arxiu i Biblioteca Episcopal, MS 43 (LXXX)

Vic, Arxiu i Biblioteca Episcopal, MS 44 (XXXVI)

Vic, Arxiu i Biblioteca Episcopal, MS 47 (LXXXVIII)

Vic, Arxiu i Biblioteca Episcopal, MS 128 A (XLVII A)

Vic, Arxiu i Biblioteca Episcopal, MS 128 B (XLVII B)

Vic, Arxiu i Biblioteca Episcopal, MS 128 C (XLVII C)

Vic, Arxiu i Biblioteca Episcopal, MS 129 (XLIII)

Vic, Arxiu i Biblioteca Episcopal, MS 130 (III)

Vic, Arxiu i Biblioteca Episcopal, MS 207

Vic, Arxiu i Biblioteca Episcopal, Fragm. XII/13

Vilanova del Vallès, Arxiu parroquial, fragment s. n.

\section{Studies}

Altés i Aguiló, Francesc Xavier, La tradició codicològica i litúrgica de l'homiliari carolingi de Luculentius a Catalunya. La recensió catalana. Inventari i homilies recuperades, Miscellània litúrgica catalana 18 (2010) 71-241 [with 15 figures].

Alturo i Perucho, Jesús, La cultura llatina medieval a Catalunya. Estat de la qüestió, in: Frederic Udina i Martorell (ed.), Symposium internacional sobre els orígens de Catalunya (segles viii-xi) 1, Memorias de la Real Academia de Buenas Letras de Barcelona 23 (Barcelona, 1991) 21-48.

Alturo i Perucho, Jesús, Escritura visigótica y escritura carolina en el contexto cultural de la Cataluña del siglo ix, in: Agustin Hevia Ballina (ed.), Las raíces visigóticas de la Iglesia en España. En torno al Concilio III de Toledo. Santoral hispano-mozárabe en España, Memoria Ecclesiae 2 (Oviedo, 1991) 33-44 and 298.

Alturo i Perucho, Jesús, El fragment de còdex 2541, IV de la Biblioteca de Catalunya amb algunes notes sobre característiques paleogràfiques de la primitiva minúscula carolina catalana, in: Miscellània d'estudis dedicats a la memòria del Professor Josep Trench $i$ Òdena [= Estudis castellonencs 6, 1 (1994-1995)] (Castelló de la Plana, 1995) 95-103 [with 2 figures].

Alturo i Perucho, Jesús, Manuscrits i documents llatins d'origen català del segle ix, in: Frederic Udina i Martorell (ed.), Symposium internacional sobre els orígens de Catalunya (segles viii-xi) 1, Memorias de la Real Academia de Buenas Letras de Barcelona 23 (Barcelona, 1991) 273-280.

Alturo i Perucho, Jesús, Els tipus d'escriptura a la Catalunya dels segles viii-x, in: Catalunya a l'època carolíngia. Art $i$ cultura abans del romànic (segles ix i x) (Barcelona, 1999) 131-134 [with 9 figures].

Arnall [i Juan], [Maria] Josepa, La escritura carolina, in: Ángel Riesco Terrero (ed.), Introducción a la paleografía y la diplomática general, Letras universitarias (Madrid, 1999) 89-110 [with 13 figures]. 
Baraut [i Obiols], Cebrià, La intervenció carolíngia antifeliciana al bisbat d'Urgell i les seves conseqüències religioses i culturals (segles viii-ix), in: Josep Perarnau [i Espelt] (ed.), Jornades internacionals d'estudi sobre el bisbe Feliu d'Urgell. La Seu d'Urgell, 28-30 de septiembre de 1999. Crònica i estudis, Facultat de Teologia de Catalunya. Seminari de Teologia als Països Catalans. Studia, Textus, Subsidia 9 (Barcelona, 2000) 155-193.

Baraut [i Obiols], Cebrià, El monestir de Sant Sadurní de Tavèrnoles i els orígens del monaquisme benedictí al comtat d'Urgell, Studia Monastica 22 (1980) 253-259.

Bischoff, Bernhard, Die ältesten Handschriften der Regula S. Benedicti in Bayern, Studien und Mitteilungen zur Geschichte des Benediktinerordens 92 (1981) 7-16.

Bischoff, Bernhard, Katalog der festländischen Handschriften des neunten Jahrhunderts (mit Ausnahme der wisigotischen) vol. 1: Aachen - Lambach (Wiesbaden, 1998); vol. 2: Laon Paderborn (Wiesbaden, 2004); vol. 3: Padua - Zwickau (Wiesbaden, 2014); vol. 4: Gesamtregister (Wiesbaden, 2017).

Bonnery, André, À propos du concile de Francfort (794). L'action des moines de Septimanie dans la lutte contre l'adoptianisme, in: Rainer Berndt (ed.), Das Frankfurter Konzil von 794. Kristallisationspunkt karolingischer Kultur 2: Kultur und Theologie, Quellen und Abhandlungen zur mittelrheinischen Kirchengeschichte 80, 2 (Mainz, 1997) 767-786.

Boshof, Egon, Erzbischof Agobard von Lyon. Leben und Werk, Kölner Historische Abhandlungen 17 (Köln, 1969).

Boulhol, Pascal, Claude de Turin. Un évêque iconoclaste dans l'Occident carolingien. Étude suivie de l'édition du Commentaire sur Josué, Collection des Études Augustiniennes, Série Moyen Âge et Temps Modernes 38 (Paris, 2002).

Cavadini, John C., The Last Christology of the West. Adoptionism in Spain and Gaul, 785-820, Middle Ages Series (Philadelphia, 1993).

Cavadini, John [C.], The sources and theology of Alcuin's "De fide sanctae et individuae Trinitatis«, Traditio 46 (1991) 123-146.

Chandler, Cullen J., Carolingian Catalunya. Politics, Culture, and Identity in an Imperial Province, 778-987, Cambridge Studies in Medieval Life and Thought. Fourth Series 111 (Cambridge, 2019).

Chandler, Cullen J., Heresy and empire. The role of the Adoptionist controversy in Charlemagne's conquest of the Spanish March, The International History Review 24 (2002) 505527.

Dahlhaus-Berg, Elisabeth, Nova antiquitas et antiqua novitas. Typologische Exegese und isidorianisches Geschichtsbild, Kölner Historische Abhandlungen 23 (Köln, 1975).

Delcor, Mathias, Un monastère aux portes de la Seu d'Urgell. Sant Sadurní de Tabernoles, Les cahiers de Saint-Michel de Cuxa 17 (1986) 43-70 [with 28 figures].

Díaz y Díaz, Manuel C., La circulation des manuscrits dans la Péninsule Ibérique du viiie au xie siècle, Cahiers de civilisation médiévale 12 (1969) 219-241 and 383-392 [with 5 figures].

Dubois, Jacques and Geneviève Renaud, Introduction, in: idem (eds.), Le martyrologe d'Adon. Ses deux familles, ses trois recensions. Texte et commentaire, Sources d'histoire médiévale (Paris, 1984) ix-xix.

Engelbert, Pius (ed.), Der Codex Regularum des Benedikt von Aniane. Faksimile der Handschrift Clm 28118 der Bayerischen Staatsbibliothek München (St. Ottilien, 2016).

Engelbert, Pius, Ein karolingisches Fragment der "Concordia regularum « des Benedikt von Aniane in Reims, Revue bénédictine 126 (2016) 138-149 [with 2 figures]. 
Freeman, Ann and Paul Meyvaert (eds.), Theodulf of Orléans. Charlemagne's Spokesman against the Second Council of Nicea, Collected Studies Series 772 (Aldershot, 2003).

Gros [i Pujol], Miquel, De l'església hispana a l'església carolíngia i el canvi de litúrgia, in: Pere de Palol i Salellas and Antoni Pladevall i Font (eds.), Del romà al romànic. Història, art i cultura de la Tarraconense mediterrània entre els segles iv i x (Barcelona, 1999) 397-407.

Gros [i Pujol], Miquel, La liturgie narbonnaise témoin d'un changement rapide de rites liturgiques, in: Liturgie de l'église particulaire et liturgie de l'église universelle. Conférences de Saint-Serge 1975, Bibliotheca »Ephemerides Liturgicae«. Subsidia 7 (Rome, 1976) 127-154. Hanslik, Rudolf, Praefatio, in: idem (ed.), Benedicti Regula, CSEL 75 (Vienna, 1960), xi-lxxv. Iglesias i Fonseca, Josep Antoni, El »Martirologio« de Adón en Cataluña. Consideraciones codicológicas y paleográficas sobre dos nuevos testimonios, in: Maurilio Pérez González (ed.), Actas [del] III Congreso Hispánico de Latín Medieval (León, 26-29 de septiembre de 2002) 1 (León, 2002) 149-159.

Kéry, Lotte, Canonical Collections of the Early Middle Ages (ca. 40o-1140). A Bibliographical Guide to the Manuscripts and Literature, History of Medieval Canon Law 1 (Washington D. C., 1999).

Kettemann, Walter, Subsidia Anianensia. Überlieferungs- und textgeschichtliche Untersuchungen zur Geschichte Witiza-Benedikts, seines Klosters Aniane und der sog. "anianischen Reform «. Mit kommentierten Editionen der "Vita Benedicti Anianensis", "Notitia de servitio monasteriorum ", des "Chronicon Moissiacense"/"Anianense" sowie zweier Lokaltraditionen aus Aniane 1-2, Unpublished $\mathrm{PhD}$ thesis (Universität Duisburg, 1999) [duepublico. uni-duisburg-essen.de/servlets/DocumentServlet?id=18245].

Kottje, Raymond, Die Bußbücher Halitgars von Cambrai und des Hrabanus Maurus. Ihre Überlieferung und ihre Quellen, Beiträge zur Geschichte und Quellenkunde des Mittelalters 8 (Berlin, 1980).

Linage Conde, Antonio, L'implantació de la regla benedictina als comtats catalans, in: Marina Miquel and Margarida Sala (eds.), Temps de monestirs. Els monestirs catalans entorn l'any mil (Barcelona, 1999) 44-61 [with 11 figures].

Linage Conde, Antonio, Los orígenes del monacato benedictino en la Península Ibérica 2: La difusión de la "Regula Benedicti«, Fuentes y estudios de historia leonesa 10 (León, 1973).

Magnou-Nortier, Élisabeth, La société laïque et l'église dans la province ecclésiastique de Narbonne (zone cispyrénéenne) de la fin du viiie à la fin du xie siécle, Publications de l'Université de Toulouse-Le Mirail A 20 (Toulouse, 1974).

Mordek, Hubert, Kirchenrecht und Reform im Frankenreich. Die »Collectio vetus Gallica«, die älteste systematische Kanonessammlung des fränkischen Gallien. Studien und Edition, Beiträge zur Geschichte und Quellenkunde des Mittelalters 1 (Berlin, 1975).

Mundó [i Marcet], Anscari M., El pes de l'Europeisme en la formació nacional de Catalunya, Revista de Catalunya 3 (1986) 37-50.

Mundó [i Marcet], Anscari M. and Alturo [i Perucho], Jesús, La escritura de transición de la visigótica a la carolina en la Cataluña del siglo ix, in: Actas del VIII Coloquio del Comité Internacional de Paleografía Latina, Estudios y ensayos 6 (Madrid, 1990) 131-138.

Mundó [i Marcet], Anscari M. and Alturo [i Perucho], Jesús, Problemàtica de les escriptures dels períodes de transició i de les marginals, Cultura neolatina 58 (1998) 121-148 [with 17 figures].

Olivar [i Daydí], Alexandre, Survivances wisigothiques dans la liturgie catalano-languedocienne, in: Liturgie et musique (ixe-xive), Cahiers de Fanjeaux 17 (Toulouse, 1982) 157-172. 
Perarnau [i Espelt], Josep (ed.), Feliu d'Urgell, Facultat de Teologia de Catalunya. Seminari de Teologia als Països Catalans. Studia, Textus, Subsidia 8 (Barcelona, 1999).

Perarnau [i Espelt], Josep (ed.), Jornades internacionals d'estudi sobre el bisbe Feliu d'Urgell. La Seu d'Urgell, 28-30 de septiembre de 1999. Crònica i estudis, Facultat de Teologia de Catalunya. Seminari de Teologia als Països Catalans. Studia, Textus, Subsidia 9 (Barcelona, 2000).

Puig i Tàrrech, Armand, La Bíblia llatina en els països de llengua catalana fins al segle xiii, Revista catalana de teologia 28 (2003) 103-134.

Quentin, Henri: Les martyrologes historiques du Moyen Âge. Étude sur la formation du Martyrologe romain, Études d'histoire des dogmes et d'ancienne littérature ecclésiastique [3] (Paris, 1908) [repr. Aalen, 1969; (Uomini e mondi medievali 5. Reprints 1), Spoleto, 2002].

Rädle, Fidel, Studien zu Smaragd von Saint-Mihiel, Medium Aevum. Philologische Studien 29 (Munich, 1974).

Riess, Frank, Narbonne and Its Territory in Late Antiquity. From the Visigoths to the Arabs (Farnham, 2013).

Ríu [i Ríu], Manuel, Revisión del problema adopcionista en la diócesis de Urgel, Anuario de estudios medievales 1 (1964) 77-96.

Steck, Wolfgang, Der Liturgiker Amalarius. Eine quellenkritische Untersuchung zu Leben und Werk eines Theologen der Karolingerzeit, Münchener Theologische Studien I. Historische Abteilung 35 (St. Ottilien, 2000).

Tischler, Matthias M., How Carolingian was early medieval Catalonia?, in: Sarah Greer, Alice Hicklin and Stefan Esders. (eds.), Using and Not Using the Past After the Carolingian Empire, c. 900-c. 1050, Remembering the Medieval and Early Modern Worlds (Abingdon, 2019) 111-133.

Tischler, Matthias M., Knowledge transfer on the Carolingian periphery. The case of early medieval Catalonia, in: Nikolas Jaspert (ed.), Ibero-Mediävistik. Grundlagen, Potentiale und Perspektiven eines internationalen Forschungsfeldes, Geschichte und Kultur der Iberischen Welt (Berlin, 2020) (forthcoming).

Tischler, Matthias M., Supposed and true knowledge of the Qur'ān in early medieval Latin literature, eighth and ninth centuries, Journal of Transcultural Medieval Studies 5 (2018) 7-54.

Vones-Liebenstein, Ursula, Katalonien zwischen Maurenherrschaft und Frankenreich. Probleme um die Ablösung westgotisch-mozarabischer Kirchenstrukturen, in: Rainer Berndt (ed.), Das Frankfurter Konzil von 794. Kristallisationspunkt karolingischer Kultur 1: Politik und Kirche, Quellen und Abhandlungen zur mittelrheinischen Kirchengeschichte 80, 1 (Mainz, 1997) 453-505.

Zapke, Susana (ed.), Hispania Vetus. Manuscritos litúrgico-musicales de los orígines visigóticos a la transición francoromana (siglos ix-xii) (Bilbao, 2007).

Zimmermann, Michel, Écrire et lire en Catalogne (ixe-xiie siècle) 1-2, Bibliothèque de la Casa de Velázquez 23, 1-2 (Madrid, 2003). 